\title{
Do plants use root-derived proteases to promote the uptake of soil organic nitrogen?
}

\author{
Lucy M. Greenfield (D) P Paul W. Hill • Eric Paterson • Elizabeth M. Baggs • Davey L. Jones
}

Received: 6 May 2020 / Accepted: 15 September 2020 / Published online: 23 September 2020

(C) The Author(s) 2020

\begin{abstract}
Aims The capacity of plant roots to directly acquire organic nitrogen $(\mathrm{N})$ in the form of oligopeptides and amino acids from soil is well established. However, plants have poor access to protein, the central reservoir of soil organic N. Our question is: do plants actively secrete proteases to enhance the breakdown of soil protein or are they functionally reliant on soil microorganisms to undertake this role?

Methods Growing maize and wheat under sterile hydroponic conditions with and without inorganic $\mathrm{N}$, we measured protease activity on the root surface (root-
\end{abstract}

Responsible Editor: Ad C. Borstlap.

Electronic supplementary material The online version of this article (https://doi.org/10.1007/s11104-020-04719-6) contains supplementary material, which is available to authorized users.

L. M. Greenfield $(\bowtie) \cdot$ P. W. Hill · D. L. Jones

School of Natural Sciences, Bangor University, Gwynedd LL57 2UW, UK

e-mail: 1.greenfield@bangor.ac.uk

E. Paterson

The James Hutton Institute, Craigiebuckler, Aberdeen AB15 $8 \mathrm{QH}, \mathrm{UK}$

\section{E. M. Baggs}

Global Academy of Agriculture and Food Security, the Royal (Dick) School of Veterinary Studies, University of Edinburgh, Easter Bush Campus, Midlothian EH25 9RG, UK

D. L. Jones

SoilsWest, UWA School of Agriculture and Environment, The University of Western Australia, Perth, WA 6009, Australia bound proteases) or exogenously in the solution (free proteases). We compared root protease activities to the rhizosphere microbial community to estimate the ecological significance of root-derived proteases.

Results We found little evidence for the secretion of free proteases, with almost all protease activity associated with the root surface. Root protease activity was not stimulated under $\mathrm{N}$ deficiency. Our findings suggest that cereal roots contribute one-fifth of rhizosphere protease activity.

Conclusions Our results indicate that plant $\mathrm{N}$ uptake is only functionally significant when soil protein is in direct contact with root surfaces. The lack of protease upregulation under $\mathrm{N}$ deficiency suggests that root protease activity is unrelated to enhanced soil $\mathrm{N}$ capture.

Keywords Aminopeptidase · Peptidase · Plant nutrition $\cdot$ Proteinase $\cdot$ Root exudation

\section{Introduction}

The rhizosphere represents a zone of intense competition for nutrient resources between plant roots and soil microorganisms (Jones et al. 2009). This competition is particularly intense for low molecular weight forms of organic $\mathrm{N}$ such as amino acids, oligopeptides and urea which can be taken up and assimilated by both plants and microorganisms (Kuzyakov and Xu 2013; Moreau et al. 2019). Conventionally, it is thought that high molecular weight $\mathrm{N}$ held in soil organic matter is largely unavailable to plants and that this resource needs to be 
hydrolysed to induce solubilisation and promote plant availability (Schulten and Schnitzer 1997). This hydrolysis step has been shown to be a major bottleneck in $\mathrm{N}$ cycling in many ecosystems (Jan et al. 2009). Of the organic $\mathrm{N}$ held in soil organic matter, ca. $40 \%$ is typically present in the form of protein which enters soil mainly from plant and microbial necromass. Microorganisms release extracellular protease and deaminase enzymes into the soil to break down this protein into oligopeptides, amino acids and $\mathrm{NH}_{4}{ }^{+}$. The soluble products can then a) be taken up and assimilated by the microbial community and any excess $\mathrm{NH}_{4}{ }^{+}$excreted back into the soil, or b) taken up directly by plant roots and associated mycorrhizas (Schimel and Bennett 2004). However, some studies have reported that plant roots can also release extracellular proteases into the soil (Adamczyk et al. 2010). Although plant roots contain a wide range of intracellular proteases (Tornkvist et al. 2019), the production of extracellular proteases by plant roots has been hypothesised to have at least four distinct functions: 1) enhancing availability of $\mathrm{N}$ for nutrition, 2) defence against plant pathogenic organisms, 3) root cell expansion, and 4) regulation of proteins and peptides in response to developmental and environmental cues (i.e. signal transduction; van der Hoorn 2008; Kohli et al. 2012). In addition, roots may unwittingly release proteases into soil during apoptotic cell death (e.g. from border cells or epidermal and cortical cell death) or following lysis caused by mesofaunal damage or physical abrasion (e.g. root hairs) (Wen et al. 2007; Sun et al. 2015; Song et al. 2016). Theoretically, the use of root proteases to promote organic $\mathrm{N}$ release may reduce competition with microorganisms, given that only a small proportion of the root surface is colonised by microorganisms (Foster 1986). In addition, it may allow the spatially targeted release of exoenzymes at sites where the $\mathrm{N}$ demand is greatest (e.g. root tips). This would be similar to the well-established mechanism of phosphatase release from roots experiencing P limitation (Ciereszko et al. 2011).

Evidence that plant root proteases can increase the supply of $\mathrm{N}$ from the soil remains conflicting. For example, Godlewski and Adamczyk (2007) report that 15 different agricultural and wild plant species have the ability to release proteases. Also, their studies on Triticum aestivum (Adamczyk et al. 2008) and Allium porrum (Adamczyk et al. 2009; Adamczyk 2014) indicate that these proteases may increases levels of free amino acids in the soil. Paungfoo-Lonhienne et al.
(2008) have also observed that plants can secrete root proteases but that they also have the potential to take up exogenously supplied proteins intact via endocytosis. In contrast, Chang and Bandurski (1964) and Vágnerová and Macura (1974) both reported negligible root protease activity in cereals, while Eick and Stöhr (2009) showed no change in membrane-bound protease activity under N deficient conditions. Similarly, Synková et al. (2016) and Paungfoo-Lonhienne et al. (2008) have shown that Nicotiana tabacum, Hakea actites and Arabidopsis thaliana plants grow very poorly when supplied just with protein. Lastly, an upregulation of protease activity may occur under different nutritional stresses (e.g. P deficiency) suggesting that the response is not N-specific (Tran and Plaxton 2008). These differences in opinion could be attributed to the different methods used to measure protease activity and plant growth conditions (German et al. 2011). This is particularly the case when sampling the root secretome due to (i) the release of intracellular proteases from roots damaged during handling, (ii) contamination from seed exudates known to be rich in proteases, (iii) and difficulties in achieving or maintaining sterile conditions, particularly the elimination of root endophytes (Sánchez-López et al. 2018; Oburger and Jones 2018).

This study focuses on aminopeptidases (E.C.3.4.11) which catalyse the cleavage of $N$-terminus amino acids from peptide and protein substrates. They are involved in fundamental plant cellular processes (e.g. mitosis, meiosis, oxidative regulation) and in various aspects of plant development via degradation of storage protein (e.g. germination, senescence) (Oszywa et al. 2013; Kania and Gillner 2015; Budic et al. 2016). Plants typically encode many aminopeptidases (e.g. Arabidopsis thaliana encodes at least 28) which can have broad specificity (Ogiwara et al. 2005; Walling 2006). Scranton et al. (2012) found that leucine aminopeptidase can moonlight as a molecular chaperone to aid plant defence. In addition, aminopeptidases are induced under both drought and metal stress in the plant roots (Wang et al. 2011; Boulila-Zoghlami et al. 2011). Importantly, aminopeptidases have also been implicated in autophagy under $\mathrm{N}$ deficiency (Xia et al. 2012; Xu et al. 2019), suggesting that they are a good candidate to investigate for their role in protein- $\mathrm{N}$ mobilisation a rhizosphere context.

Investigations of the role of plant proteases in $\mathrm{N}$ acquisition have generally focused on proteases secreted from roots (Vágnerová and Macura 1974; Godlewski 
and Adamczyk 2007). Proteomic studies of the apoplast and cell wall, however, have revealed the presence of a wide range of proteases, most of which have unknown roles (Rodríguez-Celma et al. 2016; CalderanRodrigues et al. 2019). Therefore, with a focus on aminopeptidases, our aim was to determine: a) whether plants release free proteases from their roots or if the proteases remain root surface-bound, b) if proteins and/ or their breakdown products are taken up by the plant, c) if root protease activity is up- or down-regulated in the presence of inorganic $\mathrm{N}$ and, d) how root protease activity compares to rhizosphere protease activity. We hypothesise that plants will both secrete proteases from their roots but also retain surface-bound protease activity to maximise protein-N capture from soils. We also expect protease activity to be induced in the absence of an inorganic $\mathrm{N}$ supply (Godlewski and Adamczyk 2007). Finally, we hypothesise that protease activity from rhizosphere soil will be proportionally higher than for roots as it is more energetically favourable for the soil microbial community to use the products of protein hydrolysis rather than inorganic N (Abaas et al. 2012).

\section{Materials and methods}

Growth of plants

Maize (Zea mays L.) and wheat (Triticum aestivum L.) were chosen as the study species as both plants are cereals with wide agricultural use but have different $\mathrm{N}$ use efficiencies (Liang et al. 2013). Seeds were surface sterilised by shaking with $70 \%$ ethanol for $5 \mathrm{~min}$ and then with $10 \%$ sodium hypochlorite containing one drop of Tween 20 for $5 \mathrm{~min}$. The seeds were then rinsed four times in sterile, deionised water. The seeds were germinated and grown for up to two weeks in sterile Phytatrays ${ }^{\circledR}$ (Sigma-Aldrich, Poole, UK) on autoclaved agar with either inorganic $\mathrm{N}$ or zero $\mathrm{N}$ nutrient solution added. Seedlings were grown at $20^{\circ} \mathrm{C}, 12 \mathrm{~h}$ photoperiod at $500 \mu \mathrm{mol}$ photons $\mathrm{m}^{-2} \mathrm{~s}^{-1} \mathrm{PAR}$.

\section{Nutrient solution}

Seedlings were supplied with either a zero $\mathrm{N}$ nutrient solution or inorganic $\mathrm{N}$ nutrient solution in the agar. The zero $\mathrm{N}$ nutrient solution consisted of $1.5 \mathrm{mM} \mathrm{MgSO}_{4}$, $2 \mathrm{mM} \mathrm{K}_{2} \mathrm{SO}_{4}, 4 \mathrm{mM} \mathrm{CaCl} 2,1.87 \mathrm{mM} \mathrm{NaH}_{2} \mathrm{PO}_{4}$, $0.13 \mathrm{mM} \mathrm{Na}_{2} \mathrm{HPO}_{4}, 0.14 \mathrm{mM} \mathrm{H} \mathrm{H}_{3}, 0.02 \mathrm{mM}$
$\mathrm{MnSO}_{4}, 0.002 \mathrm{mM} \mathrm{ZnSO}$, $0.003 \mathrm{mM} \mathrm{CuSO}_{4}$, $0.0002 \mathrm{mM} \mathrm{Na}_{2} \mathrm{MoO}_{4}, 0.089 \mathrm{mM} \mathrm{Fe}(\mathrm{III})$-citrate in $0.1 \mathrm{mM}$ of MES buffer (pH 5.6) (Hewitt 1966). The inorganic $\mathrm{N}$ solution consisted of $4 \mathrm{mM} \mathrm{NaNO}_{3}$ and $4 \mathrm{mM} \mathrm{NH}_{4} \mathrm{Cl}$ in addition to the zero $\mathrm{N}$ nutrient solution.

Extracellular root protease: Proteases in solution

After one-week, sterile seedlings ( $n=8$ for each treatment per plant) of similar height and root length were transferred from the Phytatrays ${ }^{\circledR}$ into a pre-autoclaved hydroponic growth system. The plants were firstly placed into a $1.5 \mathrm{ml}$ Eppendorf tube with the bottom removed. This was then placed into the top of a $50 \mathrm{~cm}^{3}$ polypropylene centrifuge tube containing nutrient solution and then into a larger sterile box. Nutrient solution was injected into each centrifuge tube via silicone tubing connected to a $0.22-\mu \mathrm{m}$ filter located outside the box. The nutrient solution in the centrifuge tube was continually aerated by passing $0.22-\mu \mathrm{m}$ filtered air into the solution via silicone tubing located outside the box. An air outlet from the centrifuge tube was via silicon tubing with a hydrophobic $0.22-\mu \mathrm{m}$ filter (Supporting information, Fig. S1). Weekly, nutrient solutions were removed from the hydroponic system through a $0.22-\mu \mathrm{m}$ filter and protease activity measured. Fresh nutrient solution was then injected into each centrifuge tube through a $0.22-\mu \mathrm{m}$ filter. Nutrient solutions were changed weekly to ensure nutrients were never limited and provide a weekly time series of protease activity over the seedlings growth. A negative control consisted of nutrient solution with no plant present. All work was carried out in a sterile, laminar flow cabinet. After four weeks of growth, under the constant conditions outlined previously, the experiment was stopped. The roots and shoots were separated, the fresh weight recorded, then oven dried at $80^{\circ} \mathrm{C}$ for $24 \mathrm{~h}$ after which the dry weight was recorded.

To ensure that the system was sterile, an open Petridish with nutrient agar was placed at the bottom of the hydroponic system. At the end of the experiment, nutrient solution was plated onto nutrient agar. If no microbial growth was observed after one week at $37^{\circ} \mathrm{C}$, the system was considered sterile.

\section{Protease assay}

Leucine aminopeptidase activity was used as an exemplar to measure potential protease activity according to 
Vepsäläinen et al. (2001). The nutrient solution was pipetted $(100 \mu \mathrm{l})$ into a 96 well plate. Substrate (100 $\mathrm{\mu l}$ of $500 \mu \mathrm{M} \mathrm{L-leucine} \mathrm{7-amido-4-}$ methylcoumarin hydrochloride dissolved in sterile water and passed through a $0.22-\mu \mathrm{m}$ filter to ensure no microbial contamination) was added to the sample ( $\mathrm{pH}$ 5.7). Standards were prepared for each sample by adding $100 \mu \mathrm{l}$ of 7-amido-4-methylcoumarin (7-AMC) at different concentrations $(0,0.5,1,5,10,15,25$ and $50 \mu \mathrm{M})$ to $100 \mu \mathrm{l}$ of sample for quench correction. After a $3 \mathrm{~h}$ incubation at $20^{\circ} \mathrm{C}$, fluorescence was measured at an excitation wavelength of $335 \mathrm{~nm}$ and emission wavelength $460 \mathrm{~nm}$ on a Cary Eclipse Fluorescence Spectrophotometer (Agilent Corp., Santa Clara, CA). A calibration curve was then fitted for each sample. Blank sample and substrate measurements were subtracted from the assay reading.

Extracellular root protease: Proteases in the root

To determine surface bound root protease activity, we carried out a protease assay in situ. After two weeks of growth, plants $(n=4)$ were transferred into a sterile $50 \mathrm{~cm}^{3}$ centrifuge tube where the protease assay was carried out as described above except the assay solution consisted of $5 \mathrm{ml}$ of sterile nutrient solution and $5 \mathrm{ml}$ of $500 \mu \mathrm{M}$ L-leucine 7-amido-4-methlycoumarin hydrochloride. Plants were incubated at $20^{\circ} \mathrm{C}$ for $3 \mathrm{~h}$ in the sterile laminar flow cabinet. The plants were removed and $200 \mu \mathrm{l}$ of assay solution were pipetted into a 96-well plate for fluorescence measurement. At the end of each experiment, roots and shoots were separated and the fresh weight recorded, then oven dried at $80{ }^{\circ} \mathrm{C}$ for $24 \mathrm{~h}$ and the dry weight recorded (Supporting information, Fig. S2).

\section{${ }^{14} \mathrm{C}$-protein uptake experiment}

To determine whether plants use protein and/or its derivatives as a sole $\mathrm{N}$ source we carried out a ${ }^{14} \mathrm{C}$-protein uptake experiment. After two weeks of growth, plants $(n=4)$ were removed from the nutrient agar and placed in $10 \mathrm{~mL}$ sterile zero $\mathrm{N}$ nutrient solution in a $50 \mathrm{~cm}^{3}$ sterile centrifuge tube in a laminar flow cabinet. Each plant was placed in a sterile plastic air-tight box. Uniformly ${ }^{14} \mathrm{C}$-labelled protein from Nicotiana tabacum L. leaves $\left(1 \mathrm{ml} ; 0.064 \mathrm{mg} \mathrm{C}{ }^{-1} ; 0.0063 \mathrm{mg} \mathrm{N} \mathrm{l}^{-1}\right.$; $3.3 \mathrm{kBq} \mathrm{ml}^{-1}$; >3 kDa; custom produced by American Radiolabeled Chemicals, St Louis, MO) was secondary purified by ultrafiltration in an Amicon ${ }^{\circledR}$ stirred cell using a $3 \mathrm{kDa}$ Ultracel ${ }^{\circledR}$ cutoff membrane (Millipore UK Ltd., Watford, UK) to remove any oligopeptides and pipetted into the nutrient solution. To capture the ${ }^{14} \mathrm{CO}_{2}$ evolved from plant respiration a $1 \mathrm{M} \mathrm{NaOH}$ trap $(1 \mathrm{ml})$ was added to the box. After $24 \mathrm{~h}$ the plants were removed, and the roots washed in $0.1 \mathrm{M} \mathrm{CaCl}_{2}$. The roots and shoot were separated, weighed and dried at $80{ }^{\circ} \mathrm{C}$ for $24 \mathrm{~h}$. To measure the ${ }^{14} \mathrm{C}$ in the root and shoot biomass, the dried samples were oxidised on a Harvey OX400 Biological Oxidiser (Harvey Instruments Corp., Hillsdale, NJ, USA) and ${ }^{14} \mathrm{CO}_{2}$ captured in Oxysolve C400 Scintillant (Zinsser Analytic, Frankfurt, Germany) and ${ }^{14} \mathrm{C}$ determination using a Wallac 1414 scintillation counter with automated quench correction (PerkinElmer Inc., Waltham, MA). The amount of ${ }^{14} \mathrm{CO}_{2}$ captured was determined after addition of Optiphase HiSafe3 scintillation fluid to the $\mathrm{NaOH}$ traps and ${ }^{14} \mathrm{C}$ determination using a Wallac 1414 scintillation counter with automated quench correction (PerkinElmer Inc.). We acknowledge that we do not know the forms of ${ }^{14} \mathrm{C}$ that were taken up into the plant (i.e. intact protein or hydrolysis products such as peptides or amino acids), but we assume it is as an organic $\mathrm{N}$ compound.

\section{Rhizosphere protease activity}

To compare root protease activity to rhizosphere soil protease activity, we collected an agricultural topsoil (0$15 \mathrm{~cm}$ ) from Abergwyngregyn, UK (53 ${ }^{\circ} 14^{\prime} 29^{\prime \prime} \mathrm{N}, 4^{\circ} 01^{\prime}$ $\left.15^{\prime \prime} \mathrm{W}\right)$. The soil was characterised as a Eutric Cambisol (pH 6.8; 27.8 g C kg; $3.4 \mathrm{~g} \mathrm{~N} \mathrm{kg).} \mathrm{Soil} \mathrm{was} \mathrm{sieved}$ $(<2 \mathrm{~mm})$ and added to boxes $(8 \mathrm{~cm} \times 10.5 \mathrm{~cm} \times 4 \mathrm{~cm})$ to achieve a dry bulk density of $1 \mathrm{~g} \mathrm{~cm}^{-3}$. Maize and wheat seeds were germinated and densely planted in the soil (1 seed per $1 \mathrm{~cm}^{3}$ ) to maximise the rhizosphere effect and grown at $20^{\circ} \mathrm{C}, 12 \mathrm{~h}$ photoperiod at $500 \mu \mathrm{mol}$ photons $\mathrm{m}^{-2} \mathrm{~s}^{-1}$ PAR. Seedlings were watered daily. After 2 weeks, the rooting was dense and, therefore, all soil was considered to be rhizosphere soil. Soil was sampled and a soil slurry created by adding $0.2 \mathrm{~g}$ to $20 \mathrm{ml}$ sterile, $0.1 \mathrm{mM}$ MES buffer ( $\mathrm{pH} 5.6$ ) and shaking for $30 \mathrm{~min}$ at $250 \mathrm{rev} \mathrm{min}^{-1}$. Protease activity was also measured at the native soil $\mathrm{pH}(6.8)$ in a soil slurry with sterile, deionised water (1:100 soil:water ratio). Protease activity did not significantly differ between the two assay pHs (unpaired t test: $p=0.21$ ). Rhizosphere protease activity was compared to extracellular root protease activity under inorganic $\mathrm{N}$ treatment for each species. 
We determined the volume of root to be $0.00785 \mathrm{~cm}^{3}$ for maize and $0.00502 \mathrm{~cm}^{3}$ for wheat with $1 \mathrm{~cm}$ root length and $1 \mathrm{~mm}$ and $0.8 \mathrm{~mm}$ diameter for maize and wheat, respectively (Eq. 1).

Volume of $\operatorname{root}\left(\mathrm{cm}^{3}\right)=\pi r^{2} h$

We assumed the root density to be $1 \mathrm{~g} \mathrm{~cm}^{-3}$ and, thus, the fresh root weight to be $0.00785 \mathrm{~g}$ and $0.00502 \mathrm{~g}$ for maize and wheat respectively. Assuming, 90\% water, the dry root weight is $0.000785 \mathrm{~cm}^{3}$ and $0.000502 \mathrm{~g} \mathrm{~cm}^{-3}$ (Eq. 2).

Dry root weight $=0.1 \frac{1 \mathrm{~g} \mathrm{~cm}^{-3}}{\text { Volume of root }\left(\mathrm{cm}^{3}\right)}$

We determined the rhizosphere extent to be $2 \mathrm{~mm}$ from the root surface. Therefore, the volume of soil surrounding $1 \mathrm{~cm}$ of root would be $0.126 \mathrm{~cm}^{3}$ (Eq. 1). The soil dry bulk density is $1 \mathrm{~g} \mathrm{~cm}^{-3}$, thus, the soil weight would be $0.126 \mathrm{~g}$. We then determined the final soil weight surrounded by the root to be $0.118 \mathrm{~g}$ and $0.121 \mathrm{~g}$ of soil for maize and wheat respectively (Eq. 3).

Final soil weight $(g)$

$=$ total soil weight $(g)-$ dry weight of root $(g)$

Rhizosphere protease activity was then compared to extracellular root protease activity ( $\mu \mathrm{mol}$ AMC $\mathrm{cm}^{-1}$ $\left.\operatorname{root} \mathrm{h}^{-1}\right)$.

Statistical analysis

All experiments were performed in quadruplicate. All statistical analyses were performed on $\mathrm{R}$ version 3.5.0 (R Core Team 2018). Normality of the data was determined by Shapiro-Wilk test $(p>0.05)$ then visually checked using qqnorm plots. Homogeneity of variance of the data was determined by Bartlett test $(p>0.05)$ then visually checked using residuals vs. fitted plots. One-way ANOVAs were used to determine if there was a significant difference $(p<0.05)$ between $\mathrm{N}$ treatment for extracellular protease activity and ${ }^{14} \mathrm{C}$-labelled protein uptake for each species. Unpaired t-tests were used to determine if there was a significant difference $(p<0.05)$ between rhizosphere and extracellular root protease activity.

\section{Results}

Root protease activity

We found no evidence of protease activity in the nutrient solution that the seedlings were grown in (no significant difference from the control, unpaired t-test: $p=0.84$; data not presented). However, we did observe measurable protease activity in the in-situ protease assay. Extracellular root protease activity ranged from 2 to $5 \mu \mathrm{mol} \mathrm{AMC} \mathrm{mg}{ }^{-1}$ root $\mathrm{h}^{-1}$ in maize roots and 5-6 $\mu \mathrm{mol}$ AMC $\mathrm{mg}^{-1}$ root $\mathrm{h}^{-1}$ in wheat roots (Fig. 1). We assume all protease activity measured in situ to be extracellular root protease at or in the root surface because we found no evidence when protease activity was measured in the solution only. Protease activity was not significantly different between $\mathrm{N}$ treatments, but under the $\mathrm{N}$ addition treatments, protease activity was two times higher for maize and ca. 14\% higher for wheat $\left(\mathrm{F}_{(1,6)}=6.4, p=0.53\right.$ and $\mathrm{F}_{(1,6)}=0.13, p=$ 0.73 , respectively).

${ }^{14} \mathrm{C}$-protein uptake

We measured plant uptake of ${ }^{14} \mathrm{C}$ derived from labelled protein to determine whether the breakdown products from proteolysis were utilised by the plant. Mineralisation of ${ }^{14} \mathrm{C}$-protein to ${ }^{14} \mathrm{CO}_{2}$ was similar between $\mathrm{N}$ treatments for both maize and wheat ( $p=0.06$ and 0.54 respectively) (Fig. 2). Root uptake of ${ }^{14} \mathrm{C}$ was ca. twice as high under the inorganic $\mathrm{N}$ than zero $\mathrm{N}$ treatment in maize $(p=$ 0.03 ) (Fig. 2). However, wheat root uptake of ${ }^{14} \mathrm{C}$ protein was similar between treatments $(p=0.43)$. Uptake of ${ }^{14} \mathrm{C}$-protein into the plant shoot was ca. three times higher under inorganic $\mathrm{N}$ than zero $\mathrm{N}$ for maize and ca. twice as high for wheat $(p=0.04$ and 0.02 respectively) (Fig. 2).

Rhizosphere and root protease activity

We compared root protease activity to rhizosphere protease activity to determine the potential ecological significance of plant root protease activity. Extracellular root protease activity contributed $15 \%$ and $19 \%$ of rhizosphere protease activity (Fig. 3) (t-test: $p=0.006$ and $p<0.0001$ for maize and wheat respectively). 
Fig. 1 Extracellular root leucine aminopeptidase activity ( $\mu \mathrm{mol}$ $\mathrm{AMC} \mathrm{mg}^{-1}$ root $\mathrm{h}^{-1}$ of maize and wheat under inorganic $\mathrm{N}$ and zero $\mathrm{N}$ treatments measured using the in situ assay. Different letters represent significant difference between $\mathrm{N}$ treatments for each plant $(p<0.05)$. Values represent mean $\pm \operatorname{SEM}(n=4)$

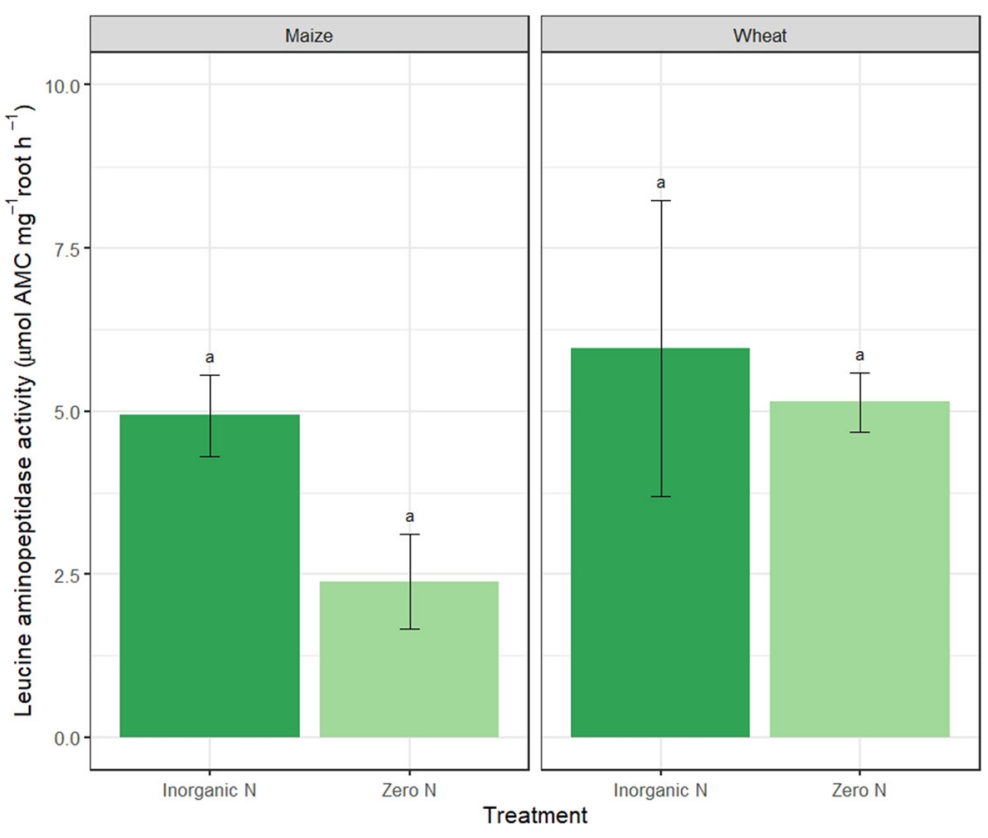

\section{Discussion}

Free versus surface bound root protease activity

Here we evaluated the possible importance of four different mechanisms for the use of protein-derived $\mathrm{N}$ by plant roots, and their likely importance in plant $\mathrm{N}$ nutrition: A) Proteases are released from the root into the external medium where they diffuse away and encounter proteins on soil surfaces and/or free in solution and the products released diffuse back to the root where they can be taken up (Adamczyk et al. 2010); B) Proteins come in direct contact with the root surface enabling cleavage by outward facing cell wall bound proteases and uptake of soluble products; C) Proteins diffuse through pores in the cell wall, entering the apoplast where plasma membrane or inward-facing cell wall bound proteases break them into soluble products (Chang and Bandurski 1964); and D) Small proteins are taken up by the root cell via endocytosis (Carpita et al. 1979) (Fig. 4). In this study we found no evidence to show that root proteases are released into the external medium in significant quantities (mechanism A), however, we did find strong evidence for root-bound protease activity (mechanisms B and C). In this study, it was not possible to determine the direct contribution of mechanism $\mathrm{D}$ as this can only be confirmed when mechanisms A and B are absent using our methods. Our findings are therefore consistent with studies of plant proteomes which have revealed a high diversity and proportion of proteases among cell wall proteins (ca. 15\% of the total; Albene et al. 2014; Canut et al. 2016). These proteases have been shown to be important regulators of plant growth and development, however, their potential role in $\mathrm{N}$ nutrition remains unclear (van der Hoorn 2008). Their known functions include: (i) breakdown of cell wall proteins to facilitate cell wall re-organisation (e.g. at the root-symbiont interface), (ii) removal of oxidised/damaged proteins (Takeda et al. 2009), (iii) the production of active peptides important for plant defence responses (immune signalling; Plattner and Verkhratsky 2015; Hou et al. 2018), (iv) the synthesis of anti-microbial peptides (Schaller et al. 2018), (iv) regulators of programmed cell death (phytaspases; Chichkova et al. 2010), (v) cell wall loosening to enable mucilage release (Rautengarten et al. 2008), and (vi) potential salvage of $\mathrm{C}$ and $\mathrm{N}$ resources in senescing tissues (Polge et al. 2009). To date, all the evidence suggests that these events are highly spatially and temporally co-ordinated in response to specific environmental stimuli and developmental cues (van der Hoorn 2008; Plattner and Verkhratsky 2015). The activity of these proteases also appears to target specific protein substrates, consistent with the view that they are not generalist proteases involved in the breakdown of soilderived protein. Although there is a lack of evidence for their direct involvement in $\mathrm{N}$ nutrition, it is clear that many could have an indirect role on $\mathrm{N}$ nutrition; for 
Fig. $2{ }^{14} \mathrm{C}$-labelled protein respired, root and shoot uptake rate $\left(\mu \mathrm{g}{ }^{14} \mathrm{C}_{\text {plant }^{-1}}\right.$ day $\left.^{-1}\right)$ of maize and wheat under inorganic $\mathrm{N}$ and zero $\mathrm{N}$ treatments. Different letters represent significant difference between $\mathrm{N}$ treatments for each plant $(p<0.05)$. Values represent mean $\pm \operatorname{SEM}(n=4)$

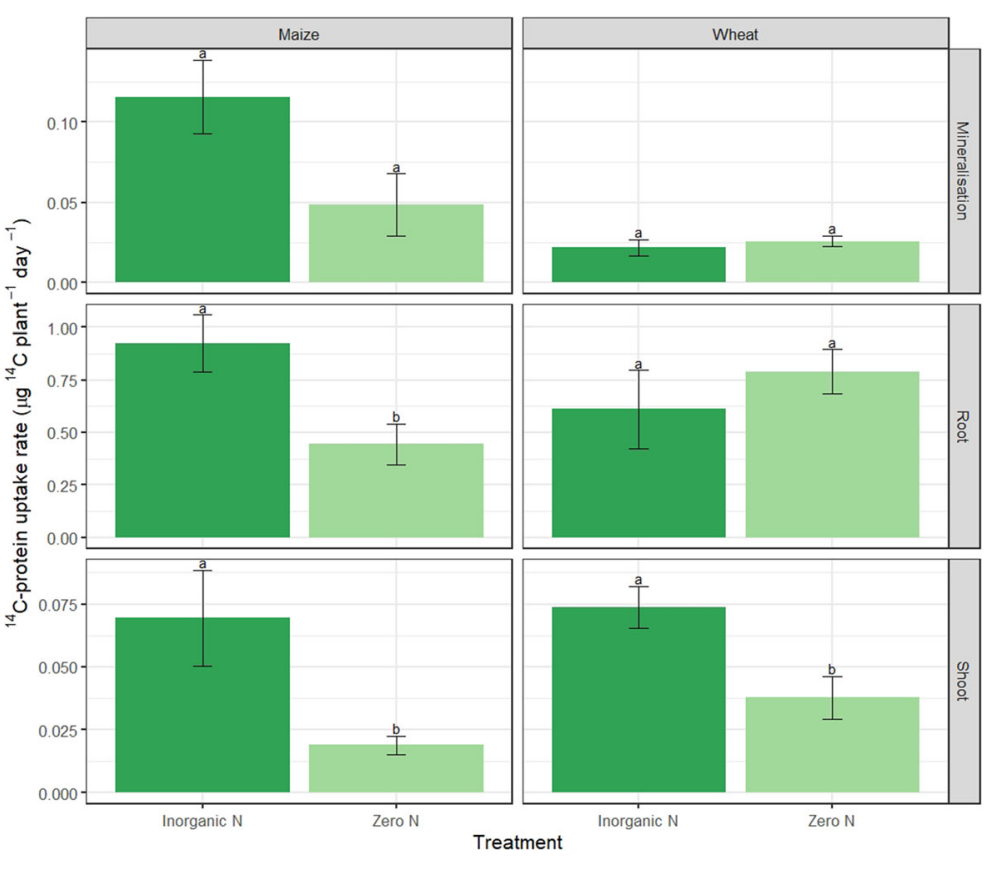

example, through improved $\mathrm{N}$ recycling and $\mathrm{N}$ use efficiency in the plant, reducing microbial growth and competition for exogenous N, enhancing soil-root contact, and promoting symbioses that promote $\mathrm{N}$ acquisition (e.g. $\mathrm{N}$ fixation, mycorrhizas). Of critical significance is that many of these proteases are upregulated in response to environmental stress (e.g. Jorda and Vera 2000; Golldack et al. 2003), a feature that was not seen in our experiments when $\mathrm{N}$ was withheld from the plants. This suggests that the degradation of exogenous proteins at the root surface is either a constitutively expressed trait, or more likely is just an indirect consequence of foreign proteins adhering to the root surface or entering the apoplast where proteolysis occurs. A similar argument has been made for the indirect capture of amino acids and peptides from soil as transporters for
Fig. 3 Comparison of leucine aminopeptidase activity in the rhizosphere and extracellular root

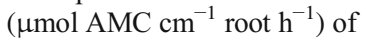
maize and wheat. Different letters represent significant difference between $\mathrm{N}$ treatments for each plant $(p<0.05)$. Values represent mean $\pm \operatorname{SEM}(n=4)$

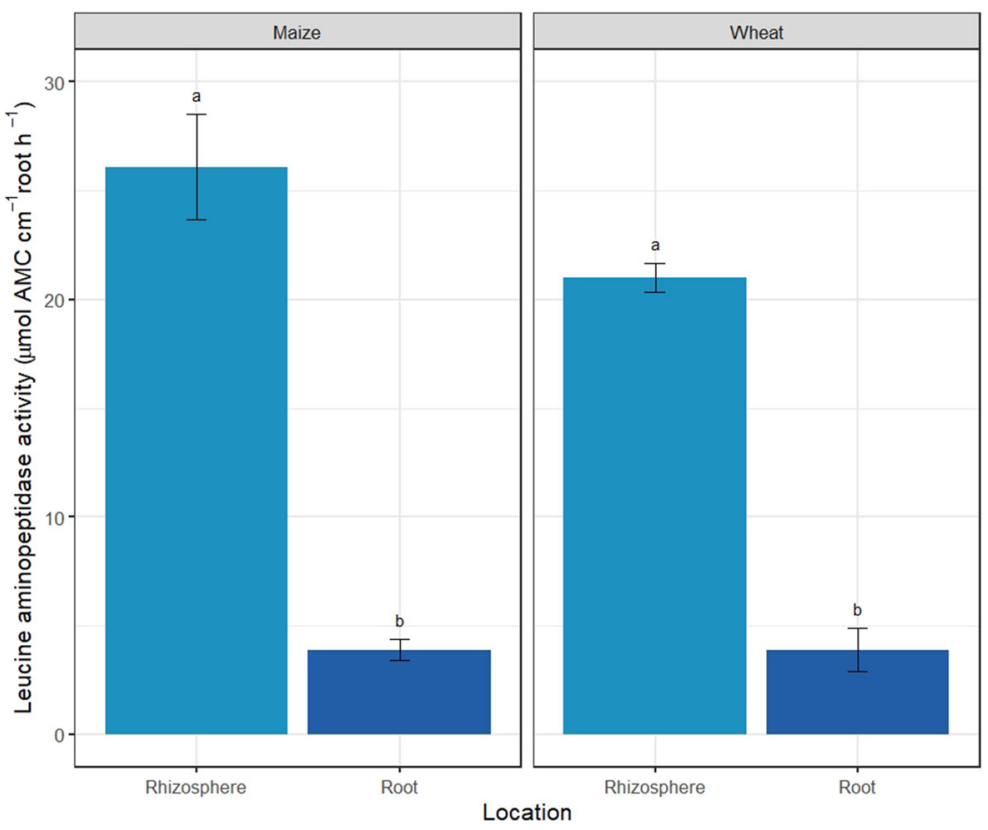


these solutes are also not up-regulated in cereals under $\mathrm{N}$ deficiency (Jones and Darrah 1994). In this latter situation, the active uptake of amino acids and oligopeptides at the epidermal surface and apoplast is likely associated with the recapture of solutes lost in root exudation by passive diffusion (Jones et al. 2009) and not uptake of organic $\mathrm{N}$ from soil (Kuzyakov and Xu 2013).

While cell wall proteases may indirectly lead to some cleavage of proteins, further action of cell wall endo/ exopeptidases may still be required to transform larger peptides into oligopeptides capable of active transport into the cell. To date, there is no evidence suggesting these enzymes are regulated by plant $\mathrm{N}$ status with most implicated in the recycling of damaged proteins (e.g. TPP(II) cell wall exopeptidase; Book et al. 2005; Polge et al. 2009). Again, this indicates that while the root possesses a full complement of enzymatic machinery required for proteolysis and the uptake of soluble products, this may have no direct involvement in $\mathrm{N}$ acquisition. One caveat we note is that our study only focused on fluorescent substrates targeted at aminopeptidases. Further studies are warranted on other types of fluorescent substrates which can target alterative proteases.

Are root proteases quantitatively important in nitrogen uptake from soil?

Most studies on the direct uptake of exogenous proteins by roots have been undertaken in the absence of soil and at very high soluble protein concentrations, conditions that might be viewed as ecologically unrealistic (White et al. 2015). In addition, even when purified protein forms are used these do not represent soil proteins and can still contain substantial amounts of oligopeptide impurities. In our study, we secondary-purified our plant-derived protein to remove oligopeptides, however, this was still added directly to the nutrient medium. In these situations, proteins tend to be attracted to the charged root surface where clumping can occur (White et al. 2015). In soil, however, it is more likely that soluble proteins will preferentially sorb to soil particles and/or denature and precipitate, hampering their movement and bioavailability (Fiorito et al. 2008). This implies that soil-borne protein needs to be in close proximity to the root surface for root-mediated, proteinderived $\mathrm{N}$ uptake to occur. This is consistent with our results and others showing that roots contain both inward and outward facing cell wall proteases (Figueiredo et al. 2018; Hou et al. 2018), indicating that they can cleave large proteins outside the cell wall (mechanism B) and either cleave or directly take up smaller ones diffusing through the cell wall (mechanism C and D; Fig. 4).

The ${ }^{14} \mathrm{C}$-labelled proteins used in this study contained a range of molecular weights $(3-100 \mathrm{kDa})$ and therefore sizes. It is likely that this also affects their potential for uptake. Conventionally, the cell wall rather than the plasma membrane is thought to represent the main barrier to protein uptake. This is due to the charged nature of the wall which induces protein binding and retention (Albene et al. 2014), but also due to the small pores (4-5 nm diameter) in the wall which prevents the inward movement of larger proteins ( $>30 \mathrm{kDa}$; Palocci et al. 2017). This is consistent with the inward movement and intact uptake of the highly stable, green fluorescent protein ( $27 \mathrm{kDa}$ ) from solution by Arabidopsis roots (mechanism D; Paungfoo-Lonhienne et al. 2008). However, Read and Bacic (1996) suggest that, albeit less frequent, 6-9 $\mathrm{nm}$ diameter pores may also exist, which would allow the ingress and potential uptake of much larger proteins (65$100 \mathrm{kDa})$, although the significance of this pathway remains unknown. We hypothesize that at least some of our ${ }^{14} \mathrm{C}$-labelled proteins would have been capable of passing through the cell wall and being available for root uptake. Unfortunately, the molecular weight distribution of proteins in soil solution remains virtually unknown. Based on the root uptake of a wide range of synthetic nanoparticles (up to $50 \mathrm{~nm}$ diameter) it also implies that this is not a protein specific pathway ( $\mathrm{Lv}$ et al. 2019). Consequently, although evidence exists for low molecular weight protein uptake, it may not necessarily mean that it is quantitatively important in $\mathrm{N}$ nutrition.

A study, that investigated whether Arabidopsis could use protein as a $\mathrm{N}$ source, found that growth was higher in plants grown on a combination of organic and inorganic $\mathrm{N}$ sources rather than protein alone (protein and inorganic $\mathrm{N}>$ inorganic $\mathrm{N}>$ protein) (PaungfooLonhienne et al. 2008). It is therefore possible that plant $\mathrm{N}$ limitation could inhibit protease synthesis. However, we would also expect that if outward facing protease activity was a preferred plant strategy under $\mathrm{N}$ limitation that it would preferentially allocate $\mathrm{N}$ resources to this function. By analogy, in the case of root $\mathrm{C}$ starvation, it 
is well established that a large proportion of intracellular protein can be degraded to provide $\mathrm{C}$ skeletons for respiration without a loss of basic metabolism (Brouquisse et al. 1991). It is also possible that the presence of proteins in the rhizosphere could induce extracellular protease production which the absence of proteins in our experiments would have prevented. However, this mechanism has only been observed in fungi so far (e.g. Hanson and Marzluf 1975; Boer and Peralta 2000). In addition, when ${ }^{14} \mathrm{C}$-labelled protein was added, the uptake of ${ }^{14} \mathrm{C}$-derived from protein into the shoot was also higher under the inorganic $\mathrm{N}$ treatment. This suggests that proteases are not induced under $\mathrm{N}$ deficiency. We hypothesise that the supply of inorganic $\mathrm{N}$ drives faster growth which in turn leads to greater cell wall reorganisation, more plasma membrane vesicle fusion events (facilitating protein internalisation) and greater cell wall protease activity.
Root versus rhizosphere protease activity

Rhizosphere protease activity was higher than extracellular root protease activity for both maize and wheat. We expected rhizosphere protease activity to be high because the rhizosphere is a hotspot for microbial activity (Kuzyakov and Blagodatskaya 2015). Soil microorganisms are largely $\mathrm{C}$ limited and they produce proteases to liberate both $\mathrm{C}$ and $\mathrm{N}$ from proteinaceous compounds, with a large proportion of the protein-C subsequently used in catabolic processes (Gonzales and RobertBaudouy 1996; Jan et al. 2009). Furthermore, they do not favour the uptake of $\mathrm{NO}_{3}{ }^{-}$as this is energetically unfavourable (Abaas et al. 2012). This contrasts with crop plants who often favour $\mathrm{NO}_{3}{ }^{-}$as a source of $\mathrm{N}$ due to its fast diffusion in soil and who are rarely $\mathrm{C}$ limited (Iqbal et al. 2020). Previous reports for protease and other enzymes (e.g. Badalucco et al. 1996; Gramss et al. 1999; Brzostek et al. 2013) have shown that roots
Fig. 4 Schematic diagram for the mechanisms of root protease activity in order to obtain $\mathrm{N}$ for nutrition

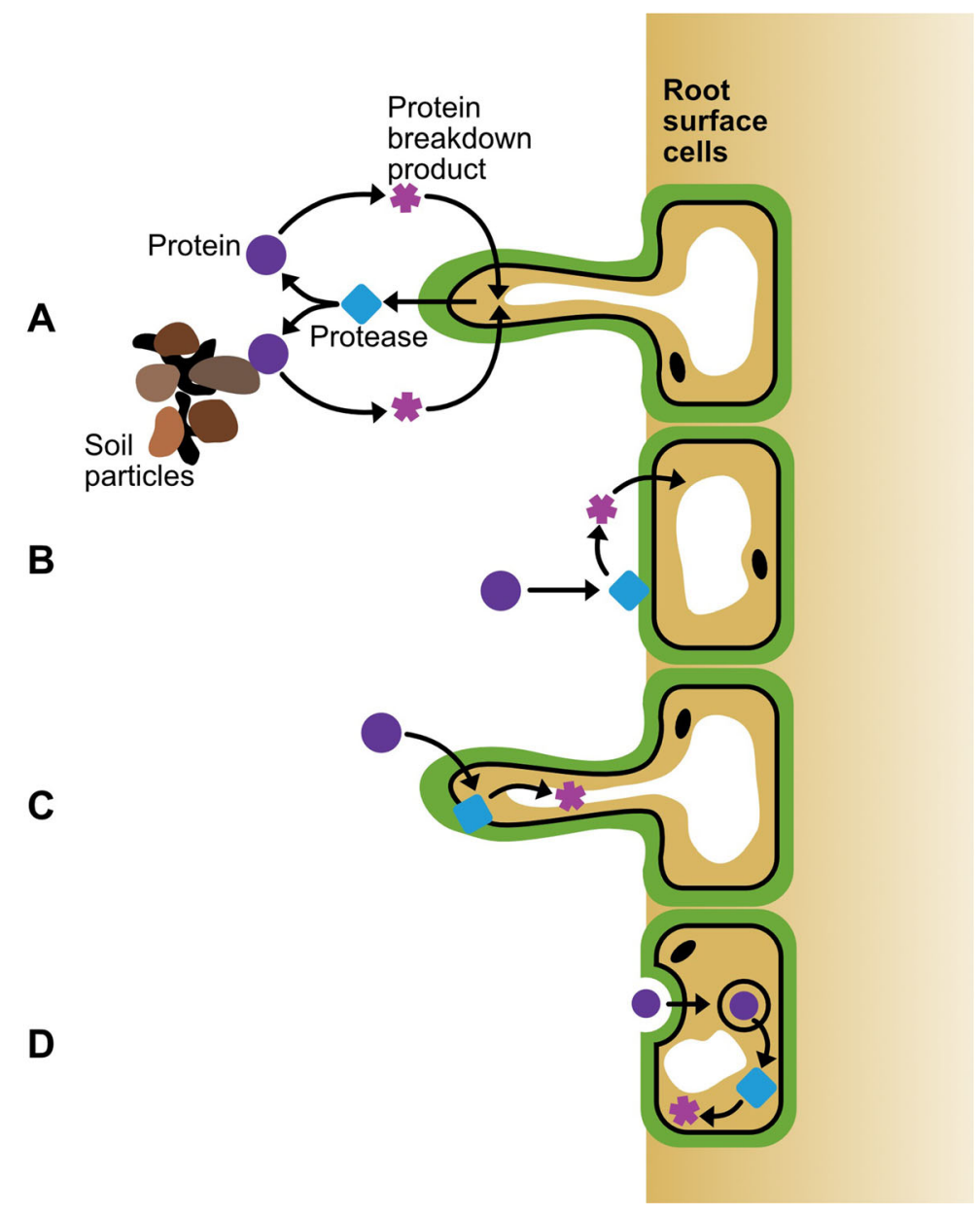


contribute little to overall rhizosphere hydrolytic activity. In contrast, our study shows up to one-fifth of rhizosphere protease activity is of root origin. In future, it is important to consider the potential contribution of plant root proteases in rhizosphere activity.

\section{Conclusions}

Although plants have the potential to contribute to rhizosphere protease activity and possess the capacity to take up and metabolise protein breakdown products, current evidence suggests that this plays a minor role in N nutrition. Our study found no evidence for the rootrelease of proteases into the soil solution. In contrast, we present strong evidence for root-bound protease activity and breakdown of soluble proteins. However, our results suggest that the use of exogenous protein may be an indirect by-product of other processes occurring in the root. In particular, the lack of up-regulation in protease activity under $\mathrm{N}$ deficiency and low intrinsic rates of protease activity in comparison to soil microbialderived protease activity suggests it plays a minor role in overall plant $\mathrm{N}$ acquisition.

Acknowledgments Thanks to Jonathan Roberts and Sarah Chesworth for their technical support. This work was supported by the UK Biotechnology and Biological Sciences Research Council; and the Natural Environment Research Council [Grant number NE/M009106/1], by a Soils Training and Research Studentships (STARS) grant to LMG. STARS is a consortium consisting of Bangor University, British Geological Survey, Centre for Ecology and Hydrology, Cranfield University, James Hutton Institute, Lancaster University, Rothamsted Research and the University of Nottingham.

Authors' contributions All authors devised the experiment. LMG conducted the experiment work and LMG and DLJ cowrote the manuscript. All authors reviewed and edited the manuscript.Data availabilityThe data that support the findings of this study are available from the corresponding author upon reasonable request.

Open Access This article is licensed under a Creative Commons Attribution 4.0 International License, which permits use, sharing, adaptation, distribution and reproduction in any medium or format, as long as you give appropriate credit to the original author(s) and the source, provide a link to the Creative Commons licence, and indicate if changes were made. The images or other third party material in this article are included in the article's Creative Commons licence, unless indicated otherwise in a credit line to the material. If material is not included in the article's Creative Commons licence and your intended use is not permitted by statutory regulation or exceeds the permitted use, you will need to obtain permission directly from the copyright holder. To view a copy of this licence, visit http://creativecommons. org/licenses/by/4.0/.

\section{References}

Abaas E, Hill PW, Roberts P, Murphy DV, Jones DL (2012) Microbial activity differentially regulates the vertical mobility of nitrogen compounds in soil. Soil Biol Biochem 53: 120-123. https://doi.org/10.1016/j.soilbio.2012.05.003

Adamczyk B (2014) Characterization of proteases secreted by leek roots. Russ J Plant Physiol 61:714-717. https://doi. org/10.1134/S1021443714050021

Adamczyk B, Godlewski M, Smolander A, Kitunen V (2009) Degradation of proteins by enzymes exuded by Allium porrum roots-a potentially important strategy for acquiring organic nitrogen by plants. Plant Physiol Biochem 47:919925. https://doi.org/10.1016/j.plaphy.2009.05.010

Adamczyk B, Godlewski M, Zimny J, Zimny A (2008) Wheat (Triticum aestivum) seedlings secrete proteases from the roots and, after protein addition, grow well on medium without inorganic nitrogen. Plant Biol 10:718-724. https://doi.org/10.1111/j.1438-8677.2008.00079.x

Adamczyk B, Smolander A, Kitunen V, Godlewski M (2010) Proteins as nitrogen source for plants: a short story about exudation of proteases by plant roots. Plant Signal Behav 5: 817-819. https://doi.org/10.4161/psb.5.7.11699

Albene C, Canut H, Hoffman L, Jamet E (2014) Plant cell wall proteins: a large body of data, but what about runaways? Proteomes 2:224-242. https://doi.org/10.3390 /proteomes2020224

Badalucco L, Kuikman PJ, Nannipieri P (1996) Protease and deaminase activities in wheat rhizosphere and their relation to bacterial and protozoan populations. Biol Fertil Soils 23: 99-104. https://doi.org/10.1007/BF00336047

Boer CG, Peralta RM (2000) Production of extracellular protease by Aspergillus tamarii. J Basic Microbiol 40:75-81. https://doi.org/10.1002/(SICI)1521-4028(200005)40:2<75 ::AID-JOBM75>3.0.CO;2-X

Book AJ, Yang P, Scalf M, Smith LM, Vierstra RD (2005) Tripeptidyl peptidase II. An oligomeric protease complex from Arabidopsis. Plant Physiol 138:1046-1057. https://doi.org/10.1104/pp.104.057406

Boulila-Zoghlami L, Gallusci P, Holzer F, Basset G, Hjebali W, Chaibi W, Walling L, Brouquisse R (2011) Up-regulation of leucine aminopeptidase-a in cadmium-treated tomato roots. Planta 234:857-863. https://doi.org/10.1007/s00425-0111468-y

Brouquisse R, James F, Raymond P, Pradet A (1991) Study of glucose starvation in excised maize root-tips. Plant Physiol 96:619-626. https://doi.org/10.1104/pp.96.2.619

Brzostek ER, Greco A, Drake JE, Finzi AC (2013) Root carbon inputs to the rhizosphere stimulate extracellular enzyme activity and increase nitrogen availability in temperate forest soils. Biogeochemistry 115:65-76. https://doi.org/10.1007 /s10533-012-9818-9 
Budic M, Cigic B, Sostaric M, Sabotic J, Meglic V, Kos J, Kidric M (2016) The response of aminopeptidases of Phaseolus vulgaris to drought depends on the developmental stage of the leaves. Plant Physiol Biochem 109:326-336. https://doi. org/10.1016/j.plaphy.2016.10.007

Calderan-Rodrigues MJ, Fonseca JG, de Moraes FE et al (2019) Plant cell wall proteomics: a focus on monocot species, Brachypodium distachyon, Saccharum spp. and Oryza sativa. Int J Mol Sci 20:1975. https://doi.org/10.3390 /ijms20081975

Canut H, Albene C, Jamet E (2016) Post-translational modifications of plant cell wall proteins and peptides: a survey from a proteomics point of view. Biochim Biophys Acta - Proteins Proteomics 1864:983-990. https://doi.org/10.1016/j. bbapap.2016.02.022

Carpita N, Sabularse D, Montezinos D, Delmer DP (1979) Determination of the pore size of cell walls of living plant cells. Science 205:1144-1147. https://doi.org/10.1126 /science.205.4411.1144

Chang CW, Bandurski RS (1964) Exocellular enzymes of corn roots. Plant Physiol 39:60-64. https://doi.org/10.1104 /pp.39.1.60

Chichkova NV, Shaw J, Galiullina RA, Drury GE, Tuzhikov AI, Kim SH, Kalkum M, Hong TB, Gorshkova EN, Torrance L, Vartapetian AB, Taliansky M (2010) Phytaspase, a relocalisable cell death promoting plant protease with caspase specificity. EMBO J 29:1149-1161. https://doi.org/10.1038 /emboj.2010.1

Ciereszko I, Szczygła A, Żebrowska E (2011) Phosphate deficiency affects acid phosphatase activity and growth of two wheat varieties. J Plant Nutr 34:815-829. https://doi.org/10.1080 /01904167.2011.544351

Eick M, Stöhr C (2009) Proteolysis at the plasma membrane of tobacco roots: biochemical evidence and possible roles. Plant Physiol Biochem 47:1003-1008. https://doi.org/10.1016/j. plaphy.2009.07.007

Figueiredo J, Sousa Silva M, Figueiredo A (2018) Subtilisin-like proteases in plant defence: the past, the present and beyond. Mol Plant Pathol 19:1017-1028. https://doi.org/10.1111 /mpp. 12567

Fiorito TM, Icoz I, Stotzky G (2008) Adsorption and binding of the transgenic plant proteins, human serum albumin, $\beta$-glucuronidase, and Cry3Bb1, on montmorillonite and kaolinite: microbial utilization and enzymatic activity of free and claybound proteins. Appl Clay Sci 39:142-150. https://doi. org/10.1016/j.clay.2007.07.006

Foster RC (1986) The ultrastructure of the rhizoplane an rhizosphere. Annu Rev Phytopathol 24:211-234. https://doi. org/10.1146/annurev.py.24.090186.001235

German DP, Weintraub MN, Grandy AS, Lauber CL, Rinkes ZL, Allison SD (2011) Optimization of hydrolytic and oxidative enzyme methods for ecosystem studies. Soil Biol Biochem 43:1387-1397. https://doi.org/10.1016/j.soilbio.2011.03.017

Godlewski M, Adamczyk B (2007) The ability of plants to secrete proteases by roots. Plant Physiol Biochem 45:657-664. https://doi.org/10.1016/j.plaphy.2007.06.001

Golldack D, Vera P, Dietz K-J (2003) Expression of subtilisin-like serine proteases in Arabidopsis thaliana is cell-specific and responds to jasmonic acid and heavy metals with developmental differences. Physiol Plant 118:64-73. https://doi. org/10.1034/j.1399-3054.2003.00087.x
Gonzales T, Robert-Baudouy J (1996) Bacterial aminopeptidases: properties and functions. FEMS Microbiol Rev 18:319-344. https://doi.org/10.1111/j.1574-6976.1996.tb00247.x

Gramss G, Voigt KD, Kirsche B (1999) Oxidoreductase enzymes liberated by plant roots and their effects on soil humic material. Chemosphere 38:1481-1494. https://doi.org/10.1016 /S0045-6535(98)00369-5

Hanson MA, Marzluf GA (1975) Control of the synthesis of a single enzyme by multiple regulatory circuits in Neurospora crassa. Proc Natl Acad Sci U S A 72:1240-1244. https://doi. org/10.1073/pnas.72.4.1240

Hewitt EJ (1966) Sand and water culture methods used in the study of plant nutrition, revised $2^{\text {nd }}$ edition. Commonwealth Agricultural Bureaux, Farnham Royal (Bucks), UK

Hou S, Jamieson P, He P (2018) The cloak, dagger, and shield: proteases in plant-pathogen interactions. Biochem J 475: 2491-2509. https://doi.org/10.1042/BCJ20170781

Iqbal A, Dong Q, Wang X, Gui HP, Zhang H, Pang N, Zhang X, Song M (2020) Nitrogen preference and genetic variation of cotton genotypes for nitrogen use efficiency. J Sci Food Agric 100:2761-2773. https://doi.org/10.1002/jsfa.10308

Jan MT, Roberts P, Tonheim SK, Jones DL (2009) Protein breakdown represents a major bottleneck in nitrogen cycling in grassland soils. Soil Biol Biochem 41:2272-2282. https://doi.org/10.1016/j.soilbio.2009.08.013

Jones DL, Darrah PR (1994) Amino-acid influx at the soil-root interface of Zea mays L. and its implications in the rhizosphere. Plant Soil 163:1-12. https://doi.org/10.1007 /BF00033935

Jones DL, Nguyen C, Finlay RD (2009) Carbon flow in the rhizosphere: carbon trading at the soil-root interface. Plant Soil 321:5-33. https://doi.org/10.1007/s11104-009-9925-0

Jorda L, Vera P (2000) Local and systemic induction of two defense-related subtilisin-like protease promoters in transgenic Arabidopsis plants. Luciferin induction of PR gene expression. Plant Physiol 124:1049-1057. https://doi. org/10.1104/pp.124.3.1049

Kania J, Gillner D (2015) Aminopeptidases isolated from plants of great economic value - role and characteristics. Chemik 69 : 466-468

Kohli A, Narciso JO, Miro B, Raorane M (2012) Root proteases: reinforced links between nitrogen uptake and mobilization and drought tolerance. Physiol Plant 145:165-179. https://doi.org/10.1111/j.1399-3054.2012.01573.x

Kuzyakov Y, Blagodatskaya E (2015) Microbial hotspots and hot moments in soil. Concept \& review 83:184-199. https://doi. org/10.1016/j.soilbio.2015.01.025

Kuzyakov Y, Xu X (2013) Competition between roots and microorganisms for nitrogen: mechanisms and ecological relevance. New Phytol 198:656-669. https://doi.org/10.1111 /nph. 12235

Liang B, Zhao W, Yang X, Zhou J (2013) Fate of nitrogen-15 as influenced by soil and nutrient management history in a 19year wheat-maize experiment. Field Crop Res 144:126-134. https://doi.org/10.1016/j.fcr.2012.12.007

Lv J, Christie P, Zhang S (2019) Uptake, translocation, and transformation of metal-based nanoparticles in plants: recent advances and methodological challenges. Environ Sci Nano 6:41-59. https://doi.org/10.1039/C8EN00645H

Moreau D, Bardgett RD, Finlay RD, Jones DL, Philippot L (2019) A plant perspective on nitrogen cycling in the rhizosphere. 
Funct Ecol 33:540-552. https://doi.org/10.1111/13652435.13303

Oburger E, Jones DL (2018) Sampling root exudates - Mission impossible? Rhizosphere 6:116-133. https://doi.org/10.1016 /j.rhisph.2018.06.004

Ogiwara N, Amano T, Satoh M, Shioi Y (2005) Leucine aminopeptidase from etiolated barley seedlings: characterization and partial purification of isoforms. Plant Sci 168:575-581. https://doi.org/10.1016/j.plantsci.2004.08.007

Oszywa B, Makowski M, Pawelczak M (2013) Purification and partial characterization of aminopeptidase from barley (Hordeum vulgare L.) seeds. Plant Physiol Biochem 65:7580. https://doi.org/10.1016/j.plaphy.2013.01.014

Palocci C, Valletta A, Chronopoulou L, Donati L, Bramosanti M, Brasili E, Baldan B, Pasqua G (2017) Endocytic pathways involved in PLGA nanoparticle uptake by grapevine cells and role of cell wall and membrane in size selection. Plant Cell Rep 36:1917-1928. https://doi.org/10.1007/s00299017-2206-0

Paungfoo-Lonhienne C, Lonhienne TGA, Rentsch D, Robinson N, Christie M, Webb RI, Gamage HK, Carroll BJ, Schenk PM, Schmidt S (2008) Plants can use protein as a nitrogen source without assistance from other organisms. Proc Natl Acad Sci U S A 105:4524-4529. https://doi.org/10.1073 /pnas.0712078105

Plattner H, Verkhratsky A (2015) The ancient roots of calcium signalling evolutionary tree. Cell Calcium 57:123-132. https://doi.org/10.1016/j.ceca.2014.12.004

Polge C, Jaquinod M, Holzer F, Bourguignon J, Walling L, Brouquisse R (2009) Evidence for the existence in Arabidopsis thaliana of the proteasome proteolytic pathway: activation in response to cadmium. J Biol Chem 284:3541235424. https://doi.org/10.1074/jbc.M109.035394

R Core Team (2018) R: A language and environment for statistical computing

Rautengarten C, Usadel B, Neumetzler L, Hartmann J, Büssis D, Altmann T (2008) A subtilisin-like serine protease essential for mucilage release from Arabidopsis seed coats. Plant J 54: 466-480. https://doi.org/10.1111/j.1365-313X.2008.03437.x

Read SM, Bacic A (1996) Cell wall porosity and its determination. In: Plant Cell Wall analysis. Springer, Berlin, pp 63-80. https://doi.org/10.1007/978-3-642-60989-3 4

Rodríguez-Celma J, Ceballos-Laita L, Grusak MA, Abadía J, López-Millán AF (2016) Plant fluid proteomics: delving into the xylem sap, phloem sap and apoplastic fluid proteomes. Biochim Biophys Acta 1864:991-1002. https://doi. org/10.1016/j.bbapap.2016.03.014

Sánchez-López AS, Pintelon I, Stevens V, Imperato V, Timmermans JP, González-Chávez C, Carrillo-González R, Van Hamme J, Vangronsveld J, Thijs S (2018) Seed endophyte microbiome of Crotalaria pumila unpeeled: identification of plant-beneficial Methylobacteria. Int J Mol Sci 19: 291. https://doi.org/10.3390/ijms19010291

Schaller A, Stintzi A, Rivas S, Serrano I, Chichkova NV, Vartapetian AB, Martínez D, Guiamét JJ, Sueldo DJ, van der Hoorn RAL, Ramírez V, Vera P (2018) From structure to function - a family portrait of plant subtilases. New Phytol 218:901-915. https://doi.org/10.1111/nph.14582

Schimel JP, Bennett J (2004) Nitrogen mineralization: challenges of a changing paradigm. Ecology 85:591-602. https://doi. org/10.1890/03-8002

Schulten H-R, Schnitzer M (1997) The chemistry of soil organic nitrogen: a review. Biol Fertil Soils 26:1-15. https://doi. org/10.1007/s003740050335

Scranton MA, Yee A, Park SY, Walling LL (2012) Plant leucine aminopeptidases moonlight as molecular chaperones to alleviate stress-induced damage. J Biol Chem 287:1840818417. https://doi.org/10.1074/jbc.M111.309500

Song Y, Ling N, Ma J, Wang J, Zhu C, Raza W, Shen Y, Huang Q, Shen Q (2016) Grafting resulted in a distinct proteomic profile of watermelon root exudates relative to the ungrafted watermelon and the rootstock plant. J Plant Growth Regul 35:778-791. https://doi.org/10.1007/s00344-0169582-5

Sun L, Song J, Peng C, Zu C, Yuan X, Shi J (2015) Mechanistic study of programmed cell death of root border cells of cucumber (Cucumber sativus L.) induced by copper. Plant Physiol Biochem 97:412-419. https://doi.org/10.1016/j. plaphy.2015.10.033

Synková H, Hýsková V, Garčeková $K$, Kř̌žžová $S$, Ryšlavá $H$ (2016) Protein as a sole source of nitrogen for in vitro grown tobacco plantlets. Biol Plant 60:635-644. https://doi. org/10.1007/s10535-016-0639-x

Takeda N, Sato S, Asamizu E, Tabata S, Parniske M (2009) Apoplastic plant subtilases support arbuscular mycorrhiza development in Lotus japonicus. Plant J 58:766-777. https://doi.org/10.1111/j.1365-313x.2009.03824.x

Tornkvist A, Liu C, Moschou P (2019) Proteolysis and nitrogen: emerging insights. J Exp Bot 70:2009-2019. https://doi. org/10.1093/jxb/erz024

Tran HT, Plaxton WC (2008) Proteomic analysis of alterations in the secretome of Arabidopsis thaliana suspension cells subjected to nutritional phosphate deficiency. Proteomics 8: 4317-4326. https://doi.org/10.1002/pmic.200800292

Vágnerová K, Macura J (1974) Determination of protease activity of plant roots. Folia Microbiol (Praha) 19:322-328. https://doi.org/10.1007/BF02873225

van der Hoorn RAL (2008) Plant proteases: from phenotypes to molecular mechanisms. Annu Rev Plant Biol 59:191-223. https://doi.org/10.1146/annurev.arplant.59.032607.092835

Vepsäläinen M, Kukkonen S, Vestberg M, Sirviö H, Niemi RM (2001) Application of soil enzyme activity test kit in a field experiment. Soil Biol Biochem 33:1665-1672. https://doi. org/10.1016/S0038-0717(01)00087-6

Walling LL (2006) Recycling or regulation? The role of aminoterminal modifying enzymes. Curr Opin Plant Biol 9:227233. https://doi.org/10.1016/j.pbi.2006.03.009

Wang D, Pan Y, Zhao X, Zhu L, Fu B, Li Z (2011) Genome-wide temporal-spatial gene expression profiling of drought responsiveness in rice. BMC Genomics 12:1-15. https://doi. org/10.1186/1471-2164-12-149

Wen F, Vanetten HD, Tsaprailis G, Hawes MC (2007) Extracellular proteins in pea root tip and border cell exudates. 
Plant Physiol 143:773-783. https://doi.org/10.1104 /pp.106.091637

White JF, Chen Q, Torres MS, Mattera R, Irizarry I, Tadych M, Bergen M (2015) Collaboration between grass seedlings and rhizobacteria to scavenge organic nitrogen in soils. AoB plants 7:plu093. https://doi.org/10.1093/aobpla/plu093

Xia TM, Xiao D, Liu D, Chai WT, Gong QQ, Wang NN (2012) Heterologous expression of ATG8c from soybean confers tolerance to nitrogen deficiency and increases yield in Arabidopsis. PLoS One 7:e37217. https://doi.org/10.1371 /journal.pone.0037217
Xu Y, Ren Y, Li J, Li L, Chen S, Wang Z, Xin Z, Chen F, Lin T, Cui D, Tong Y (2019) Comparative proteomic analysis provides new insights into low nitrogen-promoted primary root growth in hexaploid wheat. Front Plant Sci 10:151. https://doi.org/10.3389/fpls.2019.00151

Publisher's note Springer Nature remains neutral with regard to jurisdictional claims in published maps and institutional affiliations. 